\title{
Employing the Urban Education Typology Through a Critical Race Spatial Analysis
}

\author{
John A. Williams III ${ }^{1}$ (D) Marlon James ${ }^{1} \cdot$ Ana Carolina Díaz Beltrán $^{2}$. \\ Jemimah Young ${ }^{1} \cdot$ Mónica Vásquez Neshyba $^{1} \cdot$ Quinita Ogletree $^{1}$
}

Accepted: 21 October 2021 / Published online: 5 November 2021

(c) The Author(s), under exclusive licence to Springer Nature B.V. 2021

\begin{abstract}
The urban education typology put forth by Milner (Urban Educ 47(3):556-561, 2012) offered a conceptual demarcation of three different, yet interconnected types of urban school districts (i.e., urban intensive, urban emergent, and urban characteristic). Nearly one decade after Milner's seminal urban education typology, few empirical or conceptual articles have operationalized this typology across multiple school districts in one region. We enter this scholarly space to reaffirm the typology and its utility in identifying the conditions that create varying educational inequities and transformative opportunities. Through a critical race spatial analysis, we attempt to capture, crystalize, and expand Milner's typology by examining a multitude of data points and intentionally drawing on geospatial data from five linked school districts in Harris County, Texas. Our findings, as viewed through lenses of Critical Race Theory and the Chicana Feminist conceptual framework known as borderlands, accentuate two major implications; (1) while there are physical spaces of restriction inside and around schools and school districts, regularly school districts contend with identical challenges despite their urban education typology categorical classification; and (2) when employing the urban education typology, it is imperative that researchers deeply contextualize the physical, temporal, historical, social, and racialized spaces that schools and school districts exist in.
\end{abstract}

Keywords Urban education · Typology $\cdot$ Critical race spatial analysis · Borderlands

John A. Williams III

jwilliams3@tamu.edu

1 Department of Teaching, Learning and Culture, Texas A\&M University College Station, College Station, TX 77843, USA

2 University of Texas Rio Grande Valley, Brownsville, TX, USA 


\section{Introduction}

Since the burgeoning of urbanicity in the U.S. and the establishment of suburban America, the conceptualization of urban education has featured deficitbased and binary frameworks (Du Bois, 1899; Milner, 2008; Milner \& Lomotey, 2013; Noguera, 1996; Tyack, 1974; Watson, 2011). Alternatively, Milner (2012) authored a seminal editorial detailing three codifications to describe community-school level variations that became a widely used guide in urban education research. Milner's typology yielded three types of urban communities and school systems. The first type of community was urban intensive, which consisted of large population centers that are spatially dense with school districts contending with several interconnected factors that impact educational opportunities for students. Second, urban emergent was described as mid-sized cities with school districts facing new challenges related to increasing changes in density, resources, and demographic changes. Lastly, urban characteristic describes smaller school districts with limited resources that experience many of the same challenges as urban centers do. This three-tiered approach has been widely adopted by urban education researchers to distinguish inquiries in urban schools and communities from other locales.

Nevertheless, researchers continue to wrestle with how best to conceptualize "urban" throughout the last decade (Irby, 2015; Schaffer et al., 2018; Welsh \& Swain, 2020), and have to some degree attempted to accept, adapt, expand, or reject Milner's framework. Still, the classifications that Milner put forth regarding urban (i.e., intensive, characteristics, and emergent) are not all-inclusive; with Milner leaving current and future scholars the opportunity to critically address challenges and reconceptualize transformative solutions for students, families, schools, communities, and school districts throughout the U.S. Advancing and adjusting the urban education typology is critical as urban environments are continually experiencing iterative geographical adaptation and expansion according to the most recent 2020 U.S. Census Bureau report (U.S. Census Bureau, 2020). These shifts are not neutral, but create economic and social advantages for some demographic groups while initiating and/or sustaining inopportunity for the disenfranchised groups (Hochstenbach \& Musterd, 2018; Mirel, 1993). Despite a firm theoretical grounding proffered by Milner's typology, challenges related to defining and characterizing urban spaces remain.

Moreover, in Milner's typology urbanicity is operationalized through a combination of variables including the size of a city, suburban, or town, its population, access to resources for education, social challenges, and the local school district's ability to effectively educate students within the aforementioned limitations. Still, research that captures when and how school districts shift from one classification (intensive, emergent, or characteristic) is not keeping pace with the constant evolution of communities and school districts across the U.S. Additionally, scholars who employed Milner's typology regularly conceptualize communities and school districts as singular entities. Only a handful of articles stress the nuanced and plural cultural realities and locales that many schools and students transverse 
(Buendia, 2011; Diamond et al., 2020). Understanding this important reality Buendia (2011) writes, "the field of urban education has to broaden the construct of urban to accommodate the dynamism of the changing landscape (i.e., demographically and in terms of its built environment) of metropolitan areas, as well as to account for the process that contributes to these changes," (p. 18). Thus, the aims of the present inquiry are to expand Milner's urban education typology (UET) and to disrupt the association of "urban" with social pathologies when compared against its rural and suburban communities by researchers.

More to the point, this article investigates the shifting urbanicity of Houston, Katy, Spring, Humble, and Cypress-Fairbanks Independent School Districts (ISDs) located in Harris County, Texas. In traditional approaches, these ISDs would all be considered separate entities, not interconnected systems linked by socio-cultural, economic, and educational transference. Within this context, rather than using Milner's framework to label each ISD as urban intensive, urban emergent, or urban characteristic, we operationalize a third space between and within these districts. We utilize critical race spatial analysis pioneered by Morrison, Annamma, and Jackson (2017) to explain how specific segments communities and schools within these school districts are liminal spaces or borderlands (Anzaldúa, 1987; Delgado Bernal, 2009; Elenes \& Bernal, 2010). In describing these spaces, we question the traditional notion of "urban" in research, while considering a typology of dynamic borderlands of educational, employment, socioeconomic, infrastructure, and cultural exchanges through which families and education itself transverse.

What follows is a brief explanation of Milner's Urban Education Typology (UET), then a description of critical race spatial analysis and how this methodological approach is used to organize, disaggregate, analyze and interpret a web of data for Harris County, TX, and each ISD included in the present study. Our conclusion rests upon an interdisciplinary axis; one that affords a path forward to researchers, policymakers, and education practitioners attempting to better understand the field of urban education and apply transformative equitable solutions.

\section{(Re)Introducing Urban Education}

Over the past decade, scholars utilized Milner's (2012) urban education typology (UET) to categorize school(s) within their research according to descriptive traits and properties related to urbanicity in schools, communities, and school districts (Anderson \& Stillman, 2013; Milner et al., 2015; Schaffer et al., 2018; Wallace \& Chhuon, 2014). Moreover, Milner (2012) sought to solidify and separate the field of urban education from traditional research that was often undertaken without consideration of the cultural, social, or economic contexts of schools. Interestingly, his effort to legitimize urban education was warranted for two critical reasons. First, the lack of clarity amongst researchers, practitioners, and policymakers regarding how to define "urban" stagnated progress toward collectively problematizing how class, race, economics, politics, and globalization impact education in urban centers (Irby, 2015). Second, Milner's editorial unmasked a strong undercurrent that existed to alienate the field of urban education from national conversations on educational 
reform. Within this effort arose a deficit paradigm that situated students and families who live in urban areas as harbingers of social pathology, rather than victims of racial, economic, legal, and economic inequity. Thus, Milner offered a more inclusive mechanism that demonstrated the variability and similarities between urban, suburban, and rural educational systems, and the need to focus on improving the conditions that thwart students from accessing an equitable education (Diamond et al., 2020; Turner \& Spain, 2020). Hence, the UET has been and remains an essential framework for teaching, learning, researching and policy making in urban environments.

Historically, the U.S. emerged from large urban centers surrounded by suburban communities connected together through a web of rural communities. Milner's framework sought to problematize approaching education the same across these contexts. The classification urban intensive is appropriate for geographically large school districts that contend with the lack of educational resources, gaps in educational attainment, structural transportation concerns, and vast socioeconomic and social mobility inequalities. Milner's term urban emergent refers to mid-sized urban and suburban areas that manage a host of smaller-scale issues that increasingly mimic realities in central cities. Lastly, the term urban characteristic pertains to small suburban and rural towns facing new challenges associated with providing education to an increasingly diverse (culturally, economically and linguistically) student body. Yet, Milner's framework did not disrupt the traditional perspective delineating that central cities should be considered separate from surrounding suburbs and towns, and urbanicity is a byproduct of a community or town's distance from a city center. To advance research, policy, and education in urban contexts, this tradition must be interrogated and consideration must be given to how urban schooling is a non-concentric and interlaced reality. In this line of reasoning, school districts may in fact be more connected than previously theorized, and are tied together via complex social, cultural, economic, political, and spatial processes. Thus, the present inquiry seeks to expand Milner's (2012) UET framework, while addressing many of the long-standing challenges with deficit ideologies of urban pathology, and the tendency to centralize large cities as separate communities. To accomplish these goals, we focused on the transnational, racial, linguistic, economic, and culturally diverse area of Harris County, Texas, and various data from five school districts across multiple years (1990-2017). In the next section, we explicate how we leverage borderlands as a conceptual framework to guide the current study.

\section{Conceptual Framework: Borderlands}

We borrow the notion of borderlands from Chicana feminist scholarship (Anzaldúa, 1987; Delgado Bernal, 1998; Elenes \& Bernal, 2010) to describe transitioning physical, social, political, and economic spaces through the lens of interconnectedness. In these spaces exist gentrified enclaves of intercultural trans-boundary regions (Iossifova, 2013). Beyond physical space, borderlands also refer to the cultural expression and race relations that transcend the visibility of dominant structures in the physical space. Borderlands create liminal spaces (areas that are a combination of 
multiple borderless spaces) that interconnect words, histories, logics, and spiritualities (Lugones, 1990; Newman, 2003). To situate ourselves within the borderlands means to see forms of solidarity and creativity as essential for navigating spaces created by colonialism and unequal relations of power. Anzaldúa (1987) suggests that the borderland exists as an interplay between the oppression of and the resistance by historically marginalized people. Rather than becoming passive agents held captive by political, racial, linguistic, social, national, and economic impediments, individuals who exist in the borderland cultivate psychological inferences to shield, when possible, themselves from these oppressive factors and demand structural and systemic change.

Soja $(2005,2010)$ describes the process of loosening of older territorial boundaries created in terms of political power and cultural identity as processes of deterritorialization and reterritorialization or debordering and re-bordering as a consequence of the globalization of capital, industry, and labor. Soja (2010) notes, "it is difficult to know where cities begin and end, what is urban (or even suburban) and what is not" (p. 40). Furthermore, Soja describes the "melting boundaries" of metropolitan areas as a consequence of the globalization of the economy, in a way generating the internationalization of cities. Regional urbanization is a term that describes the "urbanization of suburbia" and the "peripheralization of the urban core"; a continual phenomenon that forces the "debordering" and "rebordering" of the urban, suburban, rural border arrangement into hybrid regions (Soja, 2005, p. 41). This hybridization of spaces requires scholars and even educational practitioners to reassess how families and students contend with an assortment of geopolitical, economic, cultural, and oppressive factors across state-sanctioned racialized barriers such as cities or school districts.

We contend that discussions around these classifications of school districts must broaden beyond examining Milner's typology from the inside (urban intensive) outward (urban emergent to urban characteristics), and diligently cross-examine the multilateral existence that families and students have between each of the elements within the typology (Anzaldúa, 1987; Elenes, 1997). In essence, nestled amongst and within each of Milner's classifications are borderlands. This is a critical advancement given that communities or school districts typically do not have physically defined borders. Rather, school districts and schools can subsist between multiple cities, towns, suburbs, and villages (i.e., the school districts in our sample). We assert that dynamic zone crossing creates borderlands or meso-type cities or towns that are a mixture of neighborhoods with their own unique racial and cultural enclaves. These borderlands are connected because their residents often depend on institutional resources (e.g., labor, housing, health care, education, economic) that are most accessible regardless of where these resources are located.

To attend a school or live in a community that exists within the borderland, is to be enmeshed in a double consciousness; a synergy of multiple cultures, belonging to and alienated from the school district simultaneously (Anzaldúa, 1987; Du Bois, 1903; Elenes, 1997). As minoritized families carve out and/or sustain enclaves in new school districts, they are often met with conservative forces and systems of oppression limiting educational quality and access across multiple school districts. The field of urban education must continue to recognize the importance of Milner's 
typology, while simultaneously critiquing and broadening the descriptions of urbanized environments beyond the clear-cut categories within the typology. The future state of the field requires a typology that accounts for the overlooked communities (and schools) which did not align perfectly with Milner's descriptions (intensive, emergent, and characteristics) but that constitutes borderlands.

\section{Data and Methods}

\section{Critical Race Spatial Analysis}

To garner a better understanding of demographic, linguistic, racial, ethnic, and cultural changes within each school district, we employed a critical race spatial analysis. Morrison et al. (2017) assert that to analyze space and apparatuses that form spatial relations in educational environments without contextualizing the paramount force of race in the U.S. is to perpetuate racism, oppression, and injustice. Therefore, critical race theory (CRT) is not a separate add-on to critical spatial analysis but a vital component of this methodological tool. CRT deconstructs the racialized realities in education through five foundational elements; the concentrated forms of race and racism throughout all systemic, structural, and procedures in the U.S. (Bell, 1995; Matsuda, 1991); the unwavering challenge towards dominant ideologies (Delgado-Bernal, 2002; Ladson-Billings, 1998); the identification and dismantling of Whiteness as property (Harris, 1993); the incorporation of counter narratives and the valuing of experiential knowledge of people of color (Solórzano \& Yosso, 2002); and the usage of non-ahistorical, transdisciplinary perspectives to promote and sustain social justice (DeCuir \& Dixson, 2004; Ladson-Billings \& Tate, 1995). Through this lens it is inappropriate to define urban or urban education as areas with a high density of Black and Brown bodies. Rather, to be termed "urban" describes the racialized experiences and inequitable educational conditions that minoritized students encounter, which are nested within a web of intersecting realities (racial, ethnic, linguistic, cultural, ability) that must be interrogated.

Critical race spatial analysis (CRSA) interrogates how geographies are constructed and utilized to create, accelerate, and sustain inequities "both in process and outcomes" (Morrison et al., 2017, p. 4). Geographies are not neutral spaces, thus when performing a critical race spatial analysis, it is incumbent upon researchers to interrogate how social spaces not only reproduce oppression, but also generates false narratives about who belongs and who does not belong in a specific area, and which racialized groups are permitted to thrive along social, educational, economic, and cultural axes (DeCuir \& Dixson, 2004; Dixson et al., 2020). Thus, we chose critical spatial race analysis as the analytical approach for the present study.

Moreover, critical race spatial analysis offers a visual representation of inequities and resistance, and these visual representations can include maps, historical and contemporary data (i.e., news articles, historical documents, and other forms of media), individuals 'or groups' experiences, and statistical analyses over time (Du Bois, 1899; Farmer et al., 2020; Soja, 2010; Tate, 2008). From these elements emerge a more robust examination of the multiscalar realm (e.g., borderlands); a 
socially constructed and interconnected dimension composed of macro-geographical (global), meso-geographical (regional), and micro-geographical (local) layers (Morrison et al., 2017; Soja, 2010). To accurately proceed with a critical race spatial analysis, scholars assert that just one (spatial, historical, or social) lens is inadequate, and to truly call out systemic educational injustices requires a combined critical spatial and socio-historical analysis (Du Bois, 1903; Vélez \& Solórzano, 2017).

\section{Data}

Our analysis draws on Texas Education Agency student enrollment data for each of the ISDs, focusing keenly on shifts or trends in enrollment for Black, Latinx, and White students, socioeconomics (commonly termed economically disadvantaged), and linguistics (students with limited English proficiency or in need of bilingual or English as a second language instruction) between 2005 and the start of the 2017 academic year. While student enrollment cannot capture all the elements of culture, race, and socioeconomics in a school or school district, its incorporation highlights various contexts related to school districts' cultural dynamics that can help to unpack structural and systemic forms of oppression based on resource allocation amongst other factors.

As a critical portion of the analysis, we incorporated maps to illustrate the intersection of race, economics, housing, and space. Each map is a combination of geographic data from the Opportunity Atlas, overlayed by maps containing major transportation routes and schools by type (elementary, middle, intermediate, and high school) from Community Impact (www.CommunityImpact.com) or Google maps. The Opportunity Atlas is a comprehensive, geospatial mapping website that measures longitudinal information detailed at the neighborhood level (Opportunity Insights, n.d.). The Opportunity Atlas geospatial data draws from the 2010 Census, the 2015 American Community Survey, and federal income tax returns between the years of 1998 and 2015. The estimates were calculated for each census-tract, individual counties, and commuting zone when applicable. We focused on six factors that capture demographic, economic, cultural and social capital changes in and around each ISD. Using the most recently available data from Opportunity Atlas, we examined the rate of job growth from 2004 to 2013, the median household income from 2012 to 2016, population density in 2010, the percentage of non-White residents in 2010, and the density of jobs in 2013 within each respective ISDs' attendance boundaries. Collectively the maps and student enrollment data illustrate the complexities associated with each district's growth and diversification. We begin by offering a summation of Harris County, which encompasses all three urban categorical spaces (i.e., urban intensive, urban emergent, and urban emergent) as described in UET.

\section{Harris County as a Transnational Metroplex}

Previously a homogenous, White region in the 1990s, Harris County has become a center for racial, ethnic, cultural, and linguistic diversity with the Latinx population 


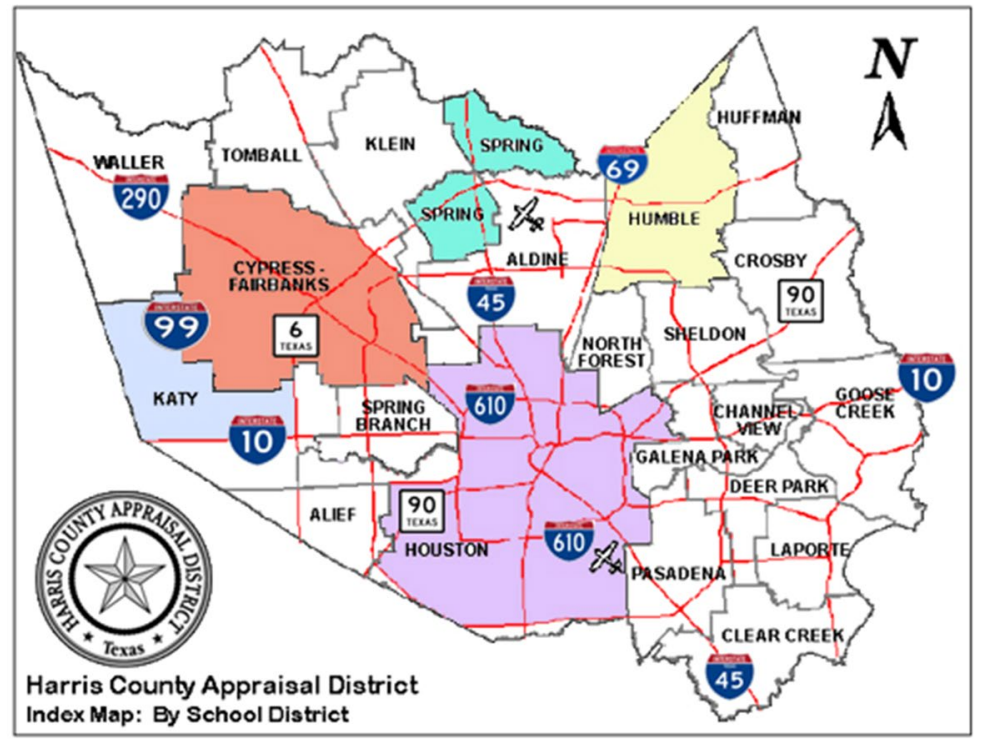

Note. Adapted from Harris County Appraisal District by School District (https://hac.csisd.org/HomeAccess)

Fig. 1 Harris County, Texas by school district map

surging from only $23 \%$ of the 2.8 million residents to $42 \%$ of the 4.4 million residents who called Harris County their home in 2012 (Kleinberg et al., 2013). The number of immigrants relocating to Harris County and births of U.S.- born Asian and Latinx, and African Americans have fueled a conglomeration of world cultures, traditions, religions, ethnicities (Klineberg, 2018). According to U.S. Census Data for 2016, Harris County is the most populous county in Texas and the third most populated county in the U.S. behind Los Angeles, California and Cook County, Illinois (U.S. Census Bureau, 2019). The three largest industries are oil and gas, wholesale, and construction, which employ over $50 \%$ of the residents in Harris County.

Additionally, Harris County has four state highways intersecting and surrounding Houston, (U.S. 99, 290, 6, and 90) and three major interstate highways (Interstate 69, 610, and 45), with the most notable being the recently renovated Interstate 10 which spans as far west as San Antonio, Texas, and traverses through the southeast corridor eastward to Jacksonville, Florida (Fig. 1). These transportation conduits served another vital role following Hurricane Katrina in 2005. Over 200,000 families from New Orleans, Louisiana relocated to Harris County with many becoming permanent residents (Mortensen et al., 2009). The majority of evacuees who relocated to Harris County were Black, non-Latino immigrants, and from low socioeconomic communities (Gabe et al., 2005; McIntosh, 2008). Each civic sector (housing, labor, healthcare, transportation, and schooling) was impacted by the influx of residents between August 2005 and October 2006 (Clettenberg et al., 2011; Graif, 2016) following Hurricane Katrina. We argue that Harris County is an appropriate site to serve as our unit of 
Table 1 Houston student enrollment from 2005 to 2017 academic year

\begin{tabular}{llllllll}
\hline Year & Total & Black & Latinx & White & Economic & LEP & BIL/ESL \\
\hline$\%$ & & $30 \%$ & $58 \%$ & $9 \%$ & $82 \%$ & $28 \%$ & $26 \%$ \\
2005 & 209,879 & 62,964 & 121,730 & 18,889 & 171,681 & 58,766 & 54,569 \\
2006 & 202,449 & 58,710 & 119,445 & 16,196 & 158,113 & 54,661 & 52,637 \\
2007 & 198,769 & 57,643 & 119,261 & 15,902 & 158,021 & 59,631 & 55,655 \\
2008 & 199,524 & 55,867 & 121,710 & 15,962 & 161,614 & 61,852 & 57,862 \\
2009 & 200,944 & 54,255 & 124,585 & 16,076 & 160,554 & 62,293 & 58,274 \\
2010 & 203,294 & 52,856 & 126,042 & 16,264 & 163,855 & 63,021 & 56,922 \\
2011 & 201,594 & 50,399 & 127,004 & 16,128 & 162,686 & 60,478 & 54,430 \\
2012 & 202,586 & 49,836 & 127,021 & 16,612 & 161,866 & 60,573 & 54,698 \\
2013 & 210,716 & 53,100 & 130,644 & 17,279 & 169,837 & 62,372 & 56,893 \\
2014 & 214,462 & 53,401 & 133,181 & 17,800 & 162,133 & 64,553 & 60,264 \\
2015 & 214,891 & 52,433 & 133,232 & 18,266 & 164,392 & 65,112 & 63,823 \\
2016 & 215,408 & 51,483 & 133,768 & 18,740 & 166,080 & 68,500 & 68,715 \\
2017 & 213,528 & 51,247 & 131,747 & 18,790 & 160,146 & 67,261 & 69,183 \\
Change & 3649 & $-11,717$ & 10,017 & -99 & $-11,535$ & 8495 & 14,615 \\
$\%$ & $1 \%$ & $24 \%$ & $62 \%$ & $9 \%$ & $75 \%$ & $32 \%$ & $32 \%$ \\
\hline
\end{tabular}

LEPP limited English proficiency, BIL bilingual, ESL English as a second language

analysis given the dynamic and evolving populous, migration trends, and unique geographic connections of the communities that make up this county.

Notwithstanding the economic toll that Hurricane Katrina exerted on Harris County, the county itself was and continues to be a bastion for income inequality (Bee, 2012). A portion of that inequality stems from the lack of accessible public transportation to growing labor markets (Galaskeiwicz et al., 2019); a concentration of hazardous waste sites in and around Black and Latinx communities which led to greater health inequities for these groups, (Bullard 1983; Charkraborty, 2020; Grineski et al., 2015; Linder et al., 2008), and the elimination of affordable housing in and around Houston as the result of racial and socioeconomic gentrification (Kinder, 2019). These conditions are a continuation of structural and systemic oppressive factors, yet, when combined, they present multiple challenges (i.e., social, academic, and employment) for school districts and the communities they serve. Harris County, through contextual analysis, offers a geospatial region large enough to examine an urban intensive (Houston), emergent (Katy, Cypress-Fairbanks, Spring), and characteristic (Humble) school districts, simultaneously. 


\section{Results}

\section{Socio-historical Context: Houston ISD}

Houston ISD (HISD) was founded in 1924. Per the Common Core Database, Houston ISD ranked as the seventh-largest school district in the U.S. (Table 1), and the largest ISD in the state of Texas as of 2016 (NCES, 2018). Houston served as a pivotal hub for relocation mainly due to the economic/labor growth around an expanding oil industry between the early 1990s to 2015. However, Houston is not a stranger to national elements impacting metropolitan landscapes such as urbanization, the exodus of low-skilled waged jobs to overseas markets, increases in immigration, housing segregation, gentrification, and social stratification via metropolitan transportation systems benefiting more affluent, White residents (Galaskeiwicz et al., 2019; Kinder Institute for Human Research, 2019; Klineberg et al., 2013; Moon, 2018; Podagrosi et al., 2011). Situated within the confluence of these socioeconomic, political, and racializing forces is HISD. The district remains challenged with responding to overcrowding K-12 classrooms, teacher shortages in critical academic specializations including bilingual education, mathematics and science, high rates of student poverty, budget restrictions, and redrawn attendance boundaries to decrease student overcrowding without restricting access to top quality magnet schools. School district administrators are placed in a precarious position when attempting to ameliorate issues across HISD. Actions to repair inequitable conditions often spawn additional inequitable conditions that are not unique to Houston ISD alone.

\section{Socio-historical Context: Cy-Fair ISD}

Similar to HISD, the other school districts in this study content with a web of similar factors but on a smaller scale. Cypress-Fairbanks (Cy-Fair) ISD is the twentysecond largest school district in the U.S., third largest in the state of Texas, and is geographically located to the northwest (along I-290, and U.S. 6) of Houston ISD, north of Katy ISD and west of Spring ISD and Humble ISD (Cy-Fair, 2013; NCES, 2018). Cy-Fair ISD is considered an urban emergent school district based on its enrollment size, spatial density, and the challenges the district encounters in accessing academic resources (i.e., high-quality and high performing teachers) and securing equitable learning outcomes for all students. Cy-Fair ISD encompasses a portion of Houston, the city of Jersey Village, Cypress, and a few unincorporated areas in Harris County. The composite demographic of Cy-Fair is particularly diverse, with $44 \%$ of the student population $(116,138)$ being Latinx as of the 2017 school year (TEA, 2018a; Table 2). Like Houston ISD, the Cy-Fair ISD student population rose because of families relocating to Harris County during the oil industry expansion in the late twentieth century. However, Cy-Fair previously existed as a rural, predominately White geographic area (Cy-Fair ISD, 2013; Lupkowski, 1984). 
Table 2 Cypress-fairbanks student enrollment from 2005 to 2017 academic year

\begin{tabular}{llllllll}
\hline Year & Total & Black & Latinx & White & Economic & LEP & BIL/ESL \\
\hline$\%$ & & $14 \%$ & $33 \%$ & $45 \%$ & $33 \%$ & $14 \%$ & $13 \%$ \\
2005 & 86,100 & 12,054 & 28,413 & 38,745 & 27,983 & 12,054 & 11,193 \\
2006 & 91,889 & 13,783 & 32,161 & 37,674 & 31,426 & 13,783 & 12,864 \\
2007 & 96,546 & 14,482 & 35,722 & 37,653 & 34,467 & 16,413 & 14,482 \\
2008 & 100,505 & 16,081 & 38,192 & 37,187 & 41,710 & 17,086 & 16,081 \\
2009 & 103,897 & 17,662 & 40,520 & 37,403 & 44,884 & 17,662 & 16,624 \\
2010 & 105,860 & 16,938 & 45,520 & 32,817 & 49,225 & 17,996 & 16,938 \\
2011 & 107,660 & 17,226 & 46,294 & 32,298 & 52,323 & 16,149 & 15,072 \\
2012 & 109,733 & 17,886 & 47,734 & 31,713 & 54,537 & 16,570 & 15,802 \\
2013 & 111,173 & 18,455 & 48,471 & 31,462 & 54,808 & 17,009 & 16,231 \\
2014 & 112,691 & 18,594 & 49,584 & 30,990 & 55,444 & 17,692 & 16,791 \\
2015 & 113,656 & 19,094 & 50,350 & 30,232 & 55,578 & 17,503 & 16,707 \\
2016 & 114,633 & 19,832 & 51,012 & 29,346 & 57,317 & 17,424 & 16,736 \\
2017 & 116,138 & 21,137 & 51,449 & 28,802 & 58,069 & 16,956 & 16,259 \\
Change & 30,038 & 9083 & 23,036 & -9943 & 30,087 & 4902 & 5066 \\
$\%$ & $34 \%$ & $18 \%$ & $44 \%$ & $29 \%$ & $50 \%$ & $15 \%$ & $14 \%$ \\
\hline
\end{tabular}

LEPP limited English proficiency, BIL bilingual, ESL English as a second language

Table 3 Katy student enrollment from 2005 to 2017 academic year

\begin{tabular}{llllllll}
\hline Year & Total & Black & Latinx & White & Economic & LEP & BIL/ESL \\
\hline$\%$ & & $9 \%$ & $26 \%$ & $57 \%$ & $23 \%$ & $11 \%$ & $11 \%$ \\
2005 & 47,808 & 4303 & 12,430 & 27,251 & 11,187 & 5259 & 5259 \\
2006 & 50,725 & 4565 & 14,203 & 26,884 & 12,326 & 6087 & 6087 \\
2007 & 53,762 & 5376 & 16,129 & 27,419 & 13,548 & 6989 & 6989 \\
2008 & 56,191 & 5619 & 17,419 & 27,534 & 15,677 & 7867 & 7305 \\
2009 & 58,444 & 5844 & 18,118 & 28,053 & 17,007 & 8182 & 7598 \\
2010 & 60,573 & 5452 & 20,595 & 26,046 & 18,293 & 8480 & 7874 \\
2011 & 62,153 & 6215 & 21,132 & 26,104 & 19,454 & 8701 & 8080 \\
2012 & 64,408 & 6183 & 22,156 & 26,858 & 19,387 & 8953 & 8888 \\
2013 & 67,015 & 6366 & 22,852 & 27,476 & 19,434 & 9516 & 9516 \\
2014 & 70,126 & 6732 & 24,193 & 27,630 & 20,056 & 11,010 & 10,940 \\
2015 & 72,725 & 7127 & 25,163 & 27,854 & 20,581 & 11,854 & 11,709 \\
2016 & 75,231 & 7749 & 26,030 & 27,760 & 21,667 & 12,714 & 12,564 \\
2017 & 77,331 & 8352 & 26,911 & 27,607 & 23,973 & 13,146 & 13,146 \\
Change & 29,523 & 4049 & 14,481 & 357 & 12,786 & 7887 & 7887 \\
$\%$ & $61 \%$ & $11 \%$ & $35 \%$ & $36 \%$ & $31 \%$ & $17 \%$ & $17 \%$ \\
\hline
\end{tabular}

LEPP limited English proficiency, $B I L$ bilingual, ESL English as a second language 
Table 4 Humble student enrollment from 2005 to 2017 academic year

\begin{tabular}{llllllll}
\hline Year & Total & Black & Latinx & White & Economic & LEP & BIL/ESL \\
\hline$\%$ & & $15 \%$ & $21 \%$ & $60 \%$ & $25 \%$ & $7 \%$ & $7 \%$ \\
2005 & 29,534 & 4430 & 6202 & 17,720 & 7443 & 2067 & 2067 \\
2006 & 31,144 & 5294 & 7163 & 17,752 & 8004 & 2492 & 2180 \\
2007 & 32,804 & 5577 & 8201 & 17,714 & 8923 & 2624 & 2624 \\
2008 & 33,724 & 6070 & 8768 & 17,874 & 9173 & 3035 & 3035 \\
2009 & 34,689 & 6244 & 9019 & 17,691 & 11,274 & 3122 & 3122 \\
2010 & 35,678 & 6422 & 9633 & 17,482 & 12,202 & 3211 & 3211 \\
2011 & 35,824 & 6448 & 10,747 & 16,479 & 12,574 & 3224 & 3224 \\
2012 & 36,867 & 6673 & 11,503 & 16,480 & 12,498 & 3171 & 3134 \\
2013 & 38,056 & 7078 & 12,178 & 16,554 & 13,129 & 3273 & 3235 \\
2014 & 39,371 & 7362 & 12,992 & 16,693 & 13,150 & 3425 & 3386 \\
2015 & 40,427 & 7722 & 13,786 & 16,535 & 13,705 & 3558 & 3477 \\
2016 & 41,125 & 8143 & 14,312 & 16,162 & 13,777 & 3660 & 3619 \\
2017 & 42,301 & 8799 & 14,975 & 16,032 & 13,663 & 3892 & 3807 \\
Change & 12,767 & 4369 & 8772 & -1688 & 6221 & 1824 & 1740 \\
$\%$ & $43 \%$ & $21 \%$ & $35 \%$ & $38 \%$ & $32 \%$ & $2 \%$ & $10 \%$ \\
\hline
\end{tabular}

LEPP limited English proficiency, BIL bilingual, ESL English as a second language

\section{Socio-historical Context: Katy ISD}

Far newer than both Cy-Fair ISD and Houston ISD, Katy ISD is the forty-seventh largest school system in the U.S. Katy ISD is the fifth-largest district in Texas with a little over 77,000 students as of the 2016-2017 academic year and the fastest growing district with a projected enrollment of over 100,000 by 2027 (Population and Survey Analysis, 2018; Table 3). Extending just west of HISD, the city of Katy experienced modest population growth over the years, with 2017 estimates projecting the city as having 14,000 residents in comparison to the 11,000 residents accounted for in the year 2000 (U.S. Census, n.d.a, n.d.b.). Nevertheless, the Greater Katy region encompasses over 300,000 residents and the growth witnessed by the region is due to the Katy Oil Fields, international events, easy highway access to and from Houston, and mass transit. For example, the Greater Kay region experienced a $300 \%$ increase of Asians locating to the area between 2000 and 2010, and in some communities south of the I-10 freeway, Asians account for $20 \%$ of the total population (Klineberg \& Wu, 2013). Additionally, Katy is home to a growing number of Venezuelans, who fled persecution from their native country of Venezuela (Herrera, 2017a; Moreno, 2004).

\section{Socio-historical Context: Humble and Spring ISD}

In contrast, both Humble and Spring ISD were formed decades prior to Katy ISD yet have similar racial demographics. Established in 1919, Humble ISD is located to the 
Table 5 Spring student enrollment from 2005 to 2017 academic year

\begin{tabular}{llllllll}
\hline Year & Total & Black & Latinx & White & Economic & LEP & BIL/ESL \\
\hline$\%$ & & $39 \%$ & $33 \%$ & $23 \%$ & $55 \%$ & $14 \%$ & $13 \%$ \\
2005 & 31,305 & 12,209 & 10,331 & 7200 & 17,249 & 4383 & 4070 \\
2006 & 32,227 & 12,569 & 11,602 & 6768 & 19,207 & 4834 & 4512 \\
2007 & 33,121 & 12,917 & 12,586 & 6293 & 21,595 & 4968 & 4968 \\
2008 & 33,882 & 13,214 & 13,214 & 5760 & 20,973 & 5760 & 5421 \\
2009 & 35,276 & 14,110 & 14,110 & 5644 & 24,058 & 5997 & 5997 \\
2010 & 36,230 & 14,492 & 14,492 & 5072 & 25,941 & 6521 & 6159 \\
2011 & 36,423 & 14,569 & 14,933 & 4735 & 26,480 & 6556 & 6192 \\
2012 & 36,028 & 14,339 & 15,348 & 4359 & 26,372 & 6773 & 6557 \\
2013 & 36,358 & 14,507 & 15,525 & 4072 & 26,978 & 7090 & 6908 \\
2014 & 36,781 & 14,676 & 15,853 & 3752 & 26,593 & 7871 & 7687 \\
2015 & 36,813 & 14,836 & 15,903 & 3571 & 25,990 & 8099 & 7915 \\
2016 & 36,654 & 14,698 & 16,164 & 3262 & 25,108 & 8430 & 8247 \\
2017 & 36,079 & 14,396 & 16,452 & 2850 & 25,075 & 8623 & 8479 \\
Change & 4774 & 2187 & 6121 & -4350 & 7826 & 4240 & 4409 \\
$\%$ & $15 \%$ & $40 \%$ & $46 \%$ & $8 \%$ & $70 \%$ & $24 \%$ & $24 \%$ \\
\hline
\end{tabular}

LEPP limited English proficiency, BIL bilingual, ESL English as a second language

northeast of Harris County and should be considered an urban characteristic district. As of 2017, almost 16,000 individuals reside in the city with African Americans comprising thirty-three percent of the total population, followed by the Latinx (28\%) and White $(21 \%)$ residents. The racial demographic of Humble ISD does not mirror the city's demographic (Table 4). Spring ISD was formed in 1935 when Harrell Common School District and Spring Common School District Combined (Spring ISD, n.d.). The district itself derives its enrollment from unincorporated portions of Harris County and the community of Spring, Texas.

Before 1995, Spring ISD was a majority White school district with only fortyfour percent of the student population being African American, Latinx, Asian, or Native American, and twenty-eight percent of the student population classified as economically disadvantaged (Mellon, 2007). Since that period, Latinx students emerged as the largest student group at forty-four percent, followed by African American (42\%) and White students (8.9). If, Native Americans (2.1\%) and Asians (3\%) students are included, Spring ISD is 90 percent students of color as of the end of the 2016-2017 academic year (Table 5). In Moreover, by 2015 in Spring ISD the percentage of students in economically disadvantaged households rose to $69 \%$ (Binkovitz and Mihir 2015). Each of the districts surrounding Houston ISD share a similar trend as they originated from unincorporated zones that needed to be formed because of an influx of citizens in that area. Spring, Humble, and Cy-Fair ISD are fairly similar in regards to being racially diverse school districts. However, each ISD — and the students learning in these areas - have been shaped by internal and external factors pertaining to access quality education. 


\section{Persistence of Educational Inequity: Houston ISD}

Seeking to better address funding inequalities, particularly along racial lines, Houston ISD in 1999 shifted to a weighted school formula which accounted for each school's student demographics (i.e., percentage of students who are refugees, economically disadvantaged, students with disabilities). This formula attempted to rebalance several inequities present in the previous funding structure (i.e., local property taxes and federal funding). Since employing this formula in 1999, Houston ISD increased the percentage of its budget to support students to $42 \%$ as of the 2017 fiscal year (HISD, n.d.; Moon, 2018), yet according to HISD (n.d.a.) budget in 2015, it still lags behind all other Harris County ISDs in regard to school district tax rates. However, the collateral damage from this change was extensive. HISD underwent a surge of school closures because of the shift, which unfortunately is a trademark of school reform in urban intensive school districts (Shaw, 2017; Williams et al., 2018). Stroub and Richards (2016) found that over seven years (2003-2010), 27 schools were eliminated in HISD. Black students and students from economically disadvantaged communities were disproportionately impacted by the closures, and only a limited number of students from low-performing schools were transferred to high-performing campuses (Stroub \& Richards, 2016).

Unfortunately, the usage of an education value-added assessment system (EVAAS) for Houston ISD created an additional issue; the removal of teachers from predominately economically disadvantaged schools with large concentrations of students of color (Amrein-Beardsley \& Geiger, 2017). By disproportionately removing teachers from already under-resourced schools, Houston ISD, which was already facing a critical shortage of bilingual teachers, further weakened its capability to provide linguistic educational services for the expanding Latinx and other immigrant populations (Ruiz de Castilla, 2018). A shortage of certified bilingual teachers contributed to the widening opportunity gap between English Language Learners (ELLs) and non-ELLs on 4th-grade reading scores (U.S. Department of Education, 2015).

\section{Persistence of Educational Inequity: Cy-Fair ISD}

While Cy-Fair ISD's administrators were not saddled with resolving funding inequalities, they still faced the matter of poor academic performance among students of color who are largely middle class. In fact, between 2004 and 2007, Cy-Fair saw Black and Latinx student performance decrease while White student performance increased (TEA, 2004, 2005, 2006). A proposed solution to the expanding education gap in Cy-Fair arose in 2013 centered on lowering student-to-teacher ratios, eliminating low-performing teachers, and reallocating their students to higher-performing teachers (Roza \& Warco, 2015). Although this proposal would increase financial savings for Cy-Fair, the move would force high-performing teachers to educate three additional students. More importantly, this shift would eliminate, not reassign, lowperforming teachers based on an unvalidated EVAAS model. 


\section{Persistence of Educational Inequity: Humble ISD}

Similar to the largest traditionally "urban" school districts of Houston and Cy-Fair, Humble ISD encountered comparable challenges but on a smaller scale. On the surface, each of Humble ISD's 41 campuses obtained "Met Standard" according to the Texas Education Agency's (2016-2017) Accountability Report (TEA, 2018b). Data from this same report highlights the district's overall success at graduating African American, Latinx, and Native American students. Furthermore, students with limited English proficiency graduated at comparable rates as their White and Asian peers within the district and across the state of Texas (TEA, 2018b). Yet, a glaring challenge district administrators sought to improve was access for students of color and students from economically disadvantaged backgrounds in advanced placement courses. The Advanced Academics Department Plan (2016-2019) highlighted that despite a student population of $21 \%$ only $16.8 \%$ of African American high school students were enrolled in advanced placement, international baccalaureate, or dual credit courses during the 2016-2017 academic year (Humble ISD, Advanced Academics Department Plan, 2016). That same year 28.8\% of LatinX students enrolled in an Advanced Academic course, which was proportional to their representation in the student body of $28 \%$. Strikingly, White students were overrepresented in enrollment in advanced academic courses (47.3\%) well beyond their overall enrollment in each of Humble's five high schools (41.3\%).

\section{Persistence of Educational Inequity: Katy ISD}

Unlike each of the previously mentioned districts, the effort to strengthen academic performance in Katy is centered more on economic segregation within Katy ISD rather than the racial disparities. On one end of the narrative, Katy ISD is exclaimed for its financial superiority to other districts and high academic achievement at the primary and secondary school level. The American Community Survey's (2018) 5-Year Estimates Report found that the largest financial difference in student poverty in Texas exists between HISD with a 36\% poverty rate and Katy ISD with $7 \%$ poverty. Still, an overlooked narrative within Katy ISD are the concentrated pockets of poverty within the city of Katy (American Community Survey, 2018). Consider for instance, Children at Risk offers a campus performance index based on socioeconomic conditions of students at the school and their academic performance on state assessments. An indication of the relationship between economic segregation and educational outcomes is visible through Children at Risk's 2017 findings (Children at Risk, 2017). For instance, only 2 in 10 of high schools in Katy were awarded exceptional status academically, while serving a student demographic that was at or above 50\% economically disadvantaged. Low performing schools predominate lowincome sections of north Katy, but in affluent neighborhoods schools south of I-10 in Katy schools are far more effective (Herrera, 2017b). 


\section{Persistence of Educational Inequity: Spring ISD}

Spring ISD encountered similar challenges as the other districts, however district leader's attempts to redress educational inequities concentrated among low income and students of color has been met with swift and organized resistance by residents who would like Spring to return to older times. For decades, the steady racial, linguistic, and economic diversification has brought about criticisms and tension from economically affluent White residents in Spring ISD. North Spring draws executives and management from Houston's oil and gas industry, given the communities close proximity to the business districts of central Houston. Under the guise of protecting their property values and establishing a lower tax rate, residents of Northgate an affluent and White subdivision in the far Northern section of Spring ISD unsuccessfully petitioned to cede from Spring ISD and join the neighboring Klein ISD in 2007 (Mellon, 2007; Spring ISD, 2007). This failed annexation into Klein still did not stop residents from complaining about the falling test scores that Spring ISD was producing, while simultaneously educating more students of color and students from low wealth families (Spencer, 2007). The proposed plan stalled due to the Spring's school board unwillingness to relinquish the property taxes generated by the highpriced homes in Northgate to Klein ISD. Spring ISD's district tax rate was and remains higher than Humble and Katy ISD at \$1.47 in 2015 (HISD, n.d.a.).

Despite a multitude of interconnected challenges, only the two largest districts (Houston and Cy-Fair) have settled on what appears to be successful approaches to supporting all students. Houston ISD has cultivated several positive outcomes for its teacher population and diverse student population. Of the five ISD's in this study, Houston has the highest completion percentage for seniors for FAFSA (The Free Application for Federal Student AID), with overwhelmingly more Black and Brown students submitting applications due to having access to full-time college advisors (Chukhray \& Salazar, 2019). Houston ISD found modest success with increasing teacher retention in the areas of mathematics and science, and improved student academic growth in the area of science and mathematics in the academic years 2012 and 2016 (Jackson \& Ahmed, 2020; Price et al., 2019). Cy-Fair ISD managed to make notable improvements to the instruction provided for students of color and economically disadvantaged students. According to the annual Children at Risk Report (2016-2017), Cy-Fair ISD increased the academic performance of their students from economically disadvantaged homes (Children at Risk, 2017). Most notably this report found that $\mathrm{Cy}$-Fair was able to add six additional schools with a Gold Ribbon Status (e.g., a school having $75 \%$ or more of their student body living in economically disadvantaged communities and achieving an $\mathrm{A} / \mathrm{B}$ academic performance rating based on Texas Education Agency data). The contextual information regarding each of the school districts highlights similar struggles with reproducing and redressing education inequity, regardless of the district's "urbanicity" as it has been traditionally defined. Still, these factors must be considered in conjunction with the spatial density of each community and the consequences for serving students. 


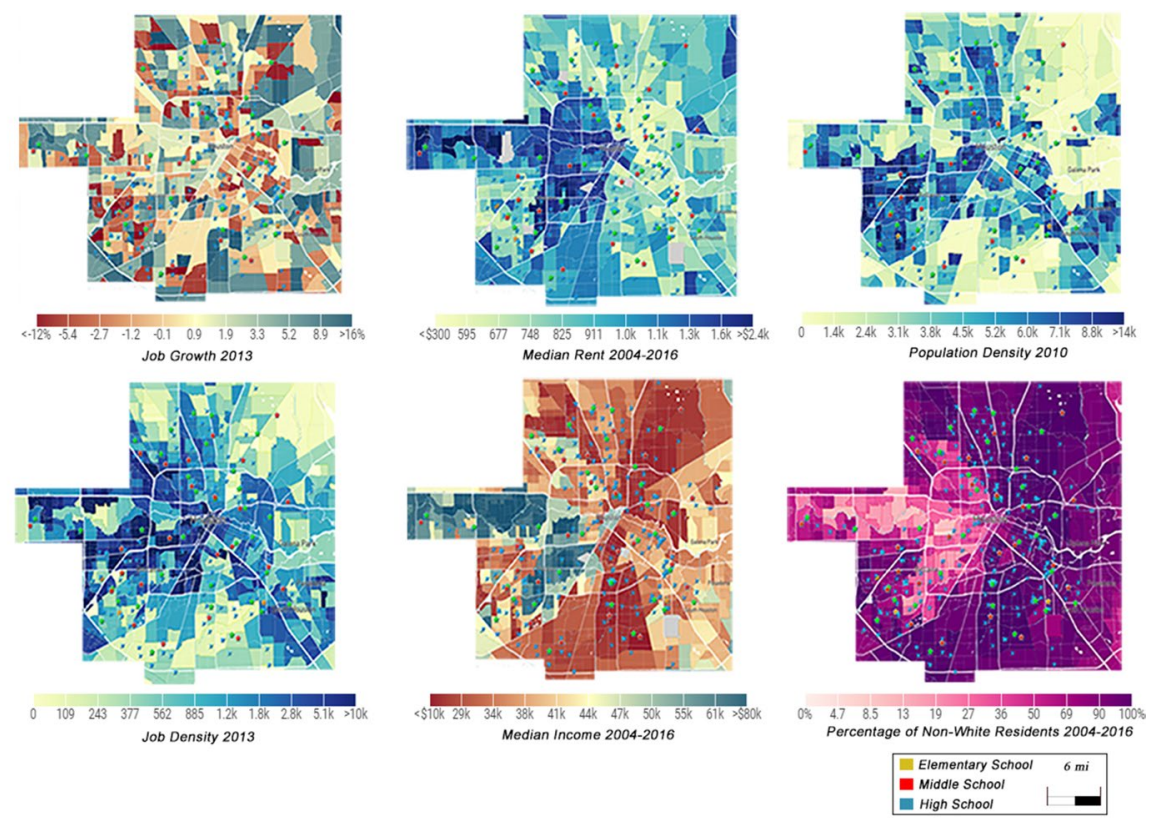

Note. Adapted from Google Maps and The Opportunity Allas (https.//wwww. opportunityatlas.org)

Fig. 2 Houston ISD spatial data

\section{The Spatial Nature of Housing, Jobs, and Income: Houston ISD}

The annual income for most households in Houston ISD is less than $\$ 44,000$ (Fig. 2), which is the lowest among the districts in this analysis. However, children who reside west of downtown live in households with a median income of $\$ 55,000$ or higher. This income distribution pattern mirrors the median rent paid in 2013 and the percentage of non-White residents in that area. Areas with a larger percentage of White residents, with higher salaries resided in higher costing homes, apartments, and condos along the Interstate 10 which leads to Katy ISD. Lastly, the map concerning job growth indicates no discernible pattern for increases and declines regarding job growth throughout Houston proper.

\section{The Spatial Nature of Housing, Jobs, and Income: Cy-Fair ISD}

Unlike Houston ISD, Fig. 3 indicates that most census tracts within Cy-Fair experienced positive job growth in 2013, with a higher portion of that job growth occurring in the upper northwest quadrant of the school district. In fact, several scattered pockets in Cy-Fair (indicated by orange and red) experienced severe job loss during 2013. Coincidentally, the eastern portion of the ISD contained more employers (i.e., job density) than the areas with the most job growth in the northwest. Regarding income and rent between 2004 and 2016, lower-income families (represented by orange and red) were centered more towards the southeast area of the district, 

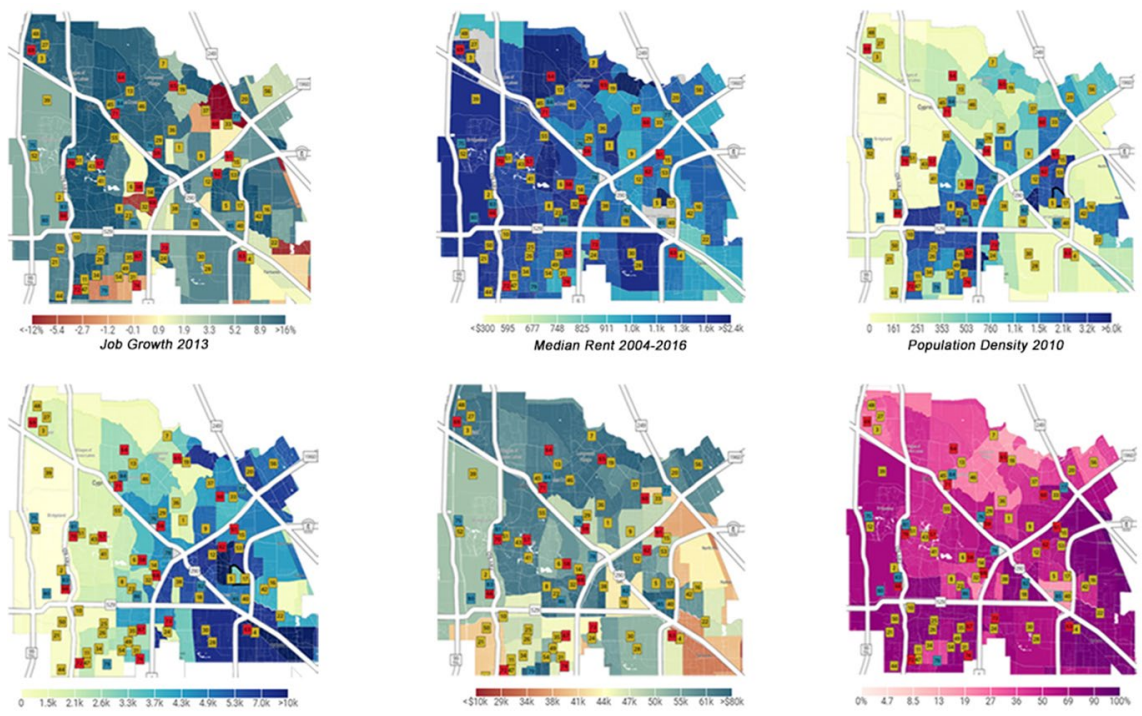

Job Density 2013

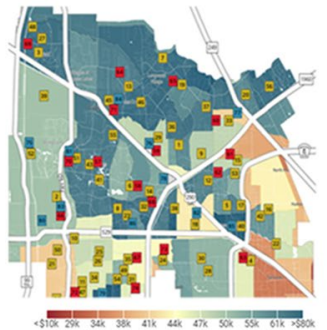

Median Income 2004-2016

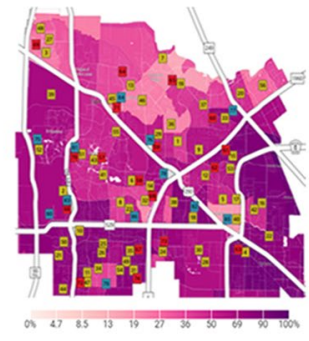

Percentage of Non-White Residents 2004-2016

Note. Adapted from Google Maps and The Opportunity Atlas (httos://www. opportunityatlas. org): and Community Impact (https.//communityimpact.org)

Fig. 3 Cypress-Fairbanks ISD spatial data

which is closer to the city of Houston and Houston ISD. However, the median rent in Cy-Fair remained consistently between $\$ 825$ and $\$ 2400$ with a difference of $\$ 1575$ between various census tract areas. Interestingly, median income differences between 2004 and 2016 occurred along Farm-to-Market (FM) 529 road and the Sam Houston Tollway, which encompasses the outer limits of Houston, and northwest portions of downtown Houston. Census tracts in the lower ranges of income directly border census tracts (and schools) across the tollway with income towards the upward range of $\$ 55,000$ to $\$ 81,000$. According to the population density in 2010 , neighborhoods with upwards of 1500 residents were congregated more around the tollway and FM 539. Additionally, the population density in the dark blue areas rival urban areas, thus there are two Cy-Fairs one that acts as an extension of and a buffer from Houston and another that is affluent.

\section{The Spatial Nature of Housing, Jobs, and Income: Katy ISD}

Katy ISD offers a similar display in regards to segments of densely populated areas. Per Fig. 4, most of the district in 2010, beyond the of the central core (in dark blue), was not densely populated (ranging between 0 and 2600 residents), which is similar to Cy-Fair ISD and several census tracts (denoted by light green) around Houston ISD (i.e., east, south, and northeast). The majority of communities in Katy ISD saw above-average job growth in 2013, from 3.3 to $10 \%$ and above. Still, families near five schools across the district (indicated by orange or red census tracts) saw no 

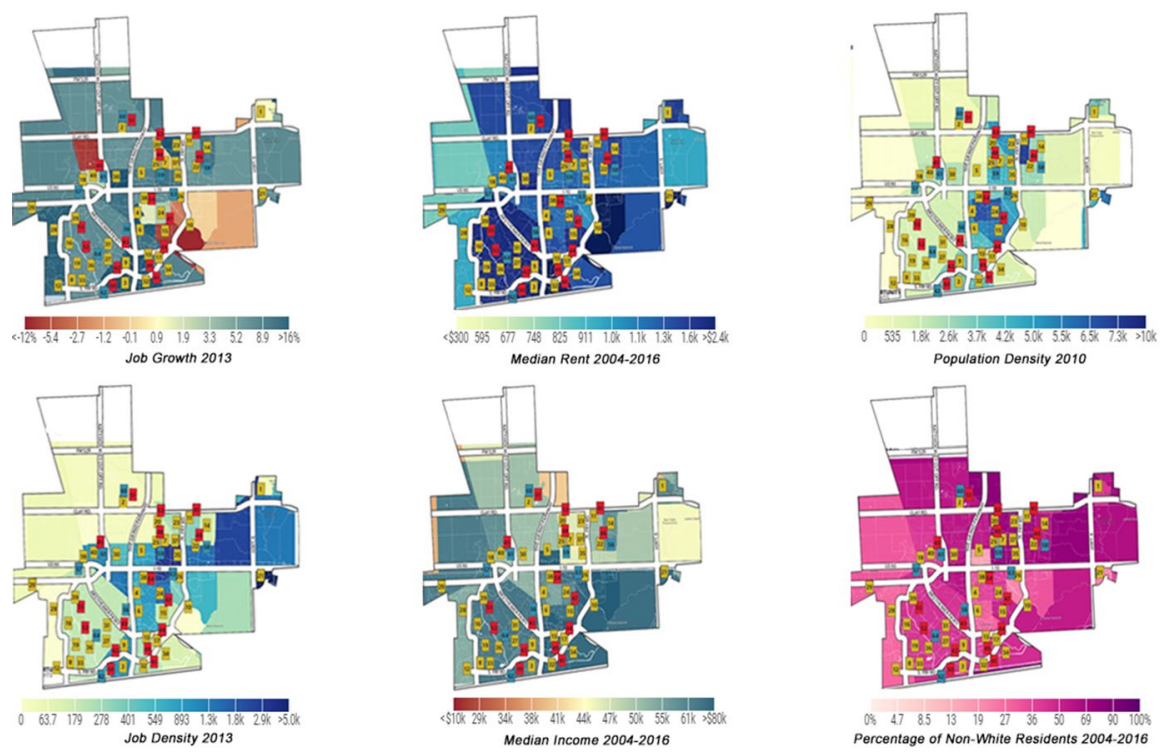

Median Rent 2004-2016

Population Density 2010
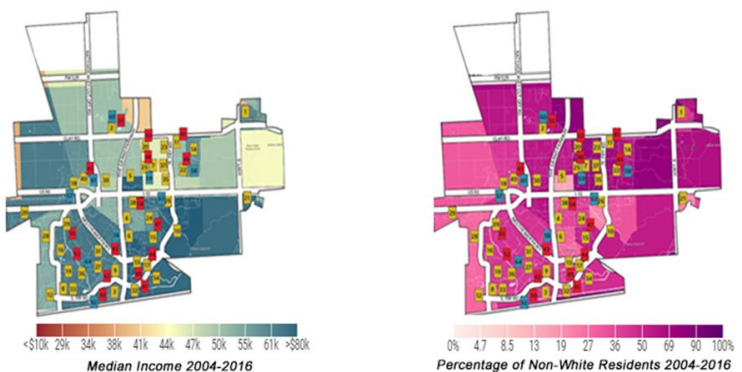

Median Income 2004-2016

Percentage of Non-White Residents 2004-2010

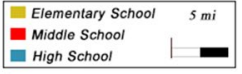

Note. Adapted from Google Maps and The Opportunity Atlas (https://www opportunityatlas. org); and Community Impact (httos://communityimpact.org)

Fig. 4 Katy ISD spatial data

job growth or witnessed jobs being eliminated in their area from -0.01 to $-12 \%$ ). Areas with higher job density (dark blue) in Katy were situated towards the east (closer towards Houston) in 2013. The map of median rent between 2004 and 2016 highlights that all schools were surrounded by housing that priced out at around \$911 to \$2400 a month. Interestingly, between 2004 and 2016 more residents of color (between 30 and 100\%) were residing north of the highway and attending 26 schools, while the majority of White residents (63-87\%) attend the remaining 41 schools south of the Highway 10.

\section{The Spatial Nature of Housing, Jobs, and Income: Humble ISD}

Humble ISD student enrollment grew by roughly 4,700 students, and the number of students in need of English language services has nearly doubled (14\% from $24 \%$ ). According to Fig. 5, the population density in 2010 was low to medium for most of the district (45.3-2000 per census tract) outside of a small region around 4 schools at the West Lake Houston Parkway, Atascocita Road, and FM 1960 junction, and the northern region of the ISD along West Lake Houston Parkway. From 2004 to 2016, Humble ISD drew the majority of its non-White students from neighborhoods south and southwest of FM 1960. The distribution of schools based on the percentage of non-White students in the district is similar, with 14 schools in predominately nonWhite census tracts, 13 located in diverse census tracts, and 15 in predominately White census tracts. In 2013, job density appeared to be dispersed across the district, 


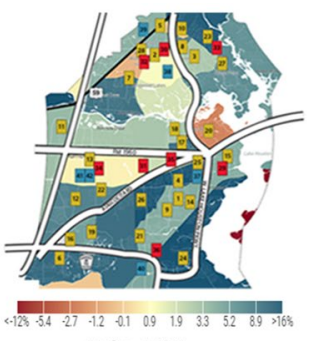

Job Growth 2013

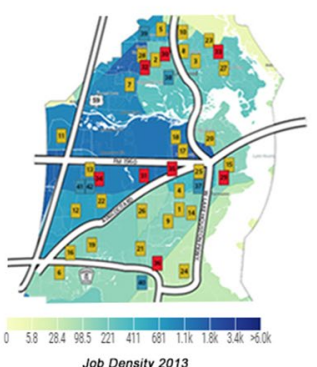

Job Density 2013

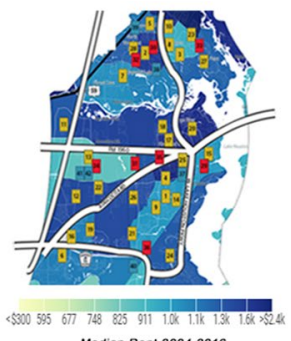

Median Rent 2004-2016

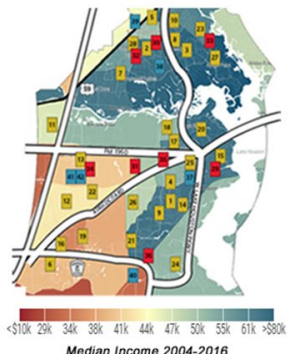

Median Income 2004-2016
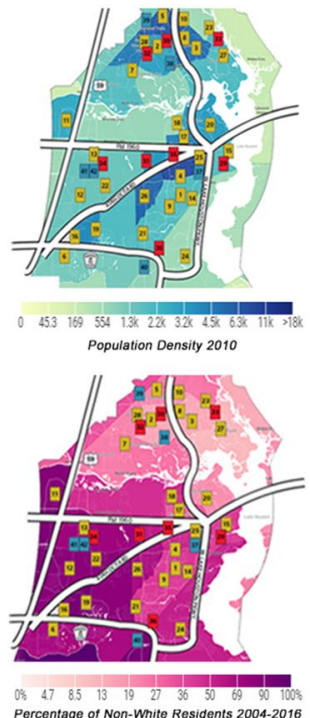

Percentage of Non-White Residents 2004-2016

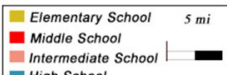

Fig. 5 Humble ISD spatial data

with slightly more dense regions located along FM 1960 and less dense areas directly south of Atascocita Road. This road cuts East to West through Spring ISD and Cy-Fair ISD and divides Katy ISD and Houston ISD. Most census tracts in the independent school district saw modest to higher percentages of job growth in 2013 (0.9-16\%), however in southern portions of the district, the job growth has not translated to higher median incomes for many residents that live south of FM 1960 and further west in Humble ISD from 2004 to 2016. The median rent for families living in this ISD ranged from $\$ 911$ to above $\$ 2400$ a month. South of FM 1960, there were 11 schools (as indicated by orange and yellow census tracts) between 2004 and 2016 that were located in what could be considered as "working-class" communities (earning between $\$ 34,000$ and \$41,000). Strikingly, these schools and community bordered neighborhoods whose median income started around $\$ 50,000$ to $\$ 61,000$; netting a difference between $\$ 16,000$ and $\$ 27,000$ in taxable income per household.

\section{The Spatial Nature of Housing, Jobs, and Income: Spring ISD}

According to Fig. 6, Spring ISDs' population only contained pockets of residential areas with a density that parallels "metropolitan" areas (dark blue), with the remaining portions of the district having between 2000 and 4500 residents per census tract. The Cypress Creek Parkway (FM 1960) and Cypress Creek (which splits the district in half) serve as artificial barriers. Immediately south of the creek (and towards HISD), the percentage of residents who are people of color ranges from 80 to $100 \%$. Just north of Cypress Creek residents of color comprise $27-78 \%$ of the population, 

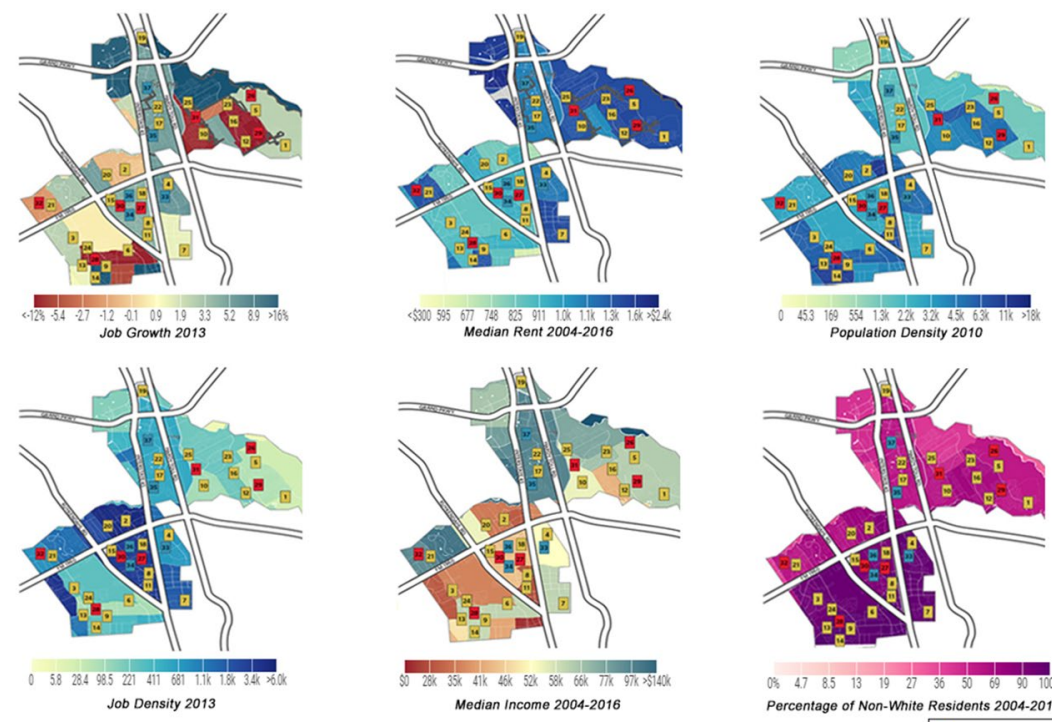

Percentage of Non-white Residents $2004-2010$

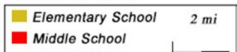

Fig. 6 Spring ISD spatial data

however, that percentage continues to drop (as low as 39\%) further north. Cypress Creek also segregates income brackets-which is a reoccurring trend in each of the school districts. For residents that reside south of the parkway (Houston), their median income between 2012 and 2016 ranged from $\$ 38,000$ to $\$ 60,000$, with much of that difference occurring between neighboring census tracts. For the bulk of communities north of the parkway, the median income per household during that time frame surpassed their southern neighbors by $\$ 2000-\$ 60,000$. Moreover, job growth was scattered throughout the district, with employment gains and declines occurring on both sides of the parkway in 2013. The median rent from 2012 to 2016 extended from above $\$ 2400$ a month in the northeast regions of the district to just below $\$ 1000$ a month in the southwestern section of the district. From 2005 to 2015, Latinx student enrollment increased, (33-46\%) followed by Black students (Table 5). Conversely, White students de-enrolled from the district by 4350 students. Spring ISD experienced the smallest enrollment percentage growth at fifteen percent in comparison to the previously mentioned ISDs. Lastly, the percentage of economically disadvantaged students rose across the district (15\%), yet a fourth (4) of their sixteen schools were located in low-income census tracts $(\$ 35,000$ or less) according to Fig. 6.

\section{Limitations}

With any spatial analysis, there exist limitations in the type and quality of data available. For example, when collecting data from Texas Education Agency (TEA), there 
was an absence of enrollment data for Asian and Native American students in 2005, which made it difficult to calculate enrollment changes during our data collection period. This limitation prevents us from fully capturing changes in racial characteristics, despite historical evidence that some districts (Katy ISD) attract more Asian students. Furthermore, demographic and spatial data is limited beyond the 2010 Census, and the 2015 American Community Survey (ACS) estimates. Potentially, any changes for the communities in and around each ISD are difficult to project beyond the ACS. Still, these limitations while important underscore the necessity for more publicly available data repositories for researchers, and future research on schools and school districts through interdisciplinary fields and research methodologies. The lag in data production can have severe consequences; with researchers potentially missing socioeconomic, linguistic, racial, ethnic, and labor market trends and their effects on educational conditions.

\section{Discussion}

The purpose of this article was to examine the urban education typology using five school districts in the same trans-spatial region, through critical race spatial analysis. In examining student enrollment trends, demographic, labor, and economic conditions around schools and school districts, we intended to solidify a gap in the urban education typology using borderlands as a conceptual framework. In glancing at the results through the borderland framework, a number of concurrent themes emerge from the critical race spatial analysis. This portion of the discussion is divided into three sections that often guide the conversation on urban education-spatial location, demographics, and resources (Milner, 2012).

\section{Location}

Critical race spatial analysis revealed that throughout Harris County, the spatial distribution of residents (density) in 2010 varied, ranging from 161 residents in one census tract to upwards of 16,000 in others. However, when examining the color distribution in each of the independent school districts there are certain schools centered in dense residential census tracts that are represented by dark blue on the maps. A noticeable difference is that Houston ISD contained multiple densely populated census tracts, whereas the surrounding ISDs had centralized clusters of residential density typically around transportation infrastructure. The urban emergent and characteristic ISDs contained multiple schools situated in the same type of spatial density as urban intensive districts, revealing that for select schools the potential for overcrowding was a reality; and a forewarning of future tensions regarding zoning and new traditional and charter school locations (Farmer et al., 2020; Spring ISD, n.d.).

The proximity of schools in relation to the communities remains a critical issue in education, particularly because historically, newer schools in suburban 
and rural districts are constructed in less racially heterogeneous communities with few public transportation options. Additionally, schools in less developed regions contend with fewer challenges as it pertains to the allocation of school resources, something that beleaguers schools in spatially dense neighborhoods (Milner, 2012). Coincidentally, during 2010 there were portions of Houston ISD (south and northeast) that were spatially less dense. The schools in these census tracts, while located in an urban intensive school district, are nestled in spatially sparse communities like ones in urban emergent or characteristic districts. Viewing these pluralities within the borderlands framework, we contend that through locality and density, schools stationed in census tracts that do not reflect the overall label of the district (urban, suburban, rural) are in a liminal space. This liminal space, when examined incorrectly can cause the misappropriation of policies, resources, and funds based on rigid categories that promote hegemony (Anzaldúa \& Keating, 2013), and ignore emerging educational inequities across intersecting social constructs (i.e., race, ethnicity, gender, income, and language, Benson, 2020). The misappropriation and misunderstanding of educational inequalities establishes a discourse which has and continues to alienate historically marginalized groups (Anzaldúa, 1987). Above all, we note that location or density mattered little to children of color, and their opportunity and access to high quality teachers and academic programs. Educational inequality regardless of how communities can be labeled was common place, and district leaders and residents clashed if racial equity was sought in any meaningful way.

\section{Resources}

We view the positioning of resources (labor markets, housing, income) as a part of the spatial densities that impact the neighborhoods around school districts, and that classically define a school district's urbanicity. Each of the aforementioned ISDs demographic transformation (size and cultural composition) is derived by the existence or lack of the aforementioned resources. Literature on super gentrification and Houston highlights the acquisition of low-income housing, the redistribution of poor residents, and the insurgence of wealthy predominately White residents in newly, overpriced neighborhoods (King \& Lowe, 2018; Podagrosi et al., 2011). Soja (2005) denotes that urban cores are undergoing deborderlization process. This deboderlization processing in Houston is fueled by the elimination of affordable housing or the refurbishing of existing historical parcels of land into multi-million dollar condos using government subsidies, where younger residents can live, eat, and socialize in trendy enclaves that radiates an air of affluence in an urban environment (Podagrosi et al., 2011; Sarnoff, 2000). This displacement is compounded by the closure of lowperforming schools, which increasingly harmfully impacts economically disadvantaged students and students of color (Stroub \& Richards, 2016). While transnational factors contributed to Houston's ensemble of cultures, recent political, economic, and educational contexts, these same factors are creating new borders, while erasing history, cultures and of the "unsafe" ghettos and instilling "safe" gentrified neighborhoods in HISD (Anzaldúa, 1987). 
A similar analysis of the urban emergent and characteristic districts is warranted pertaining to resources. Each of the tables denotes an upward trend in student enrollment, which implies overall population growth for each city and town in Katy, Humble, Spring, and Cy-Fair attendance boundaries. However, from the maps three different and connected borderlands have formed around resources. There are schools in resource affluent areas as indicated by high job growth and increased job density, which promotes higher housing costs and incomes; resource intermediate areas that have average job growth and density with affordable housing costs a high to average incomes; and resource scarce areas where job growth and the number of jobs are scant, which translated to stagnant income growth yet higher housing prices similar to resource affluent resourced areas.

Notwithstanding belonging to the same urban emergent or characteristic school district, several schools across these districts exhibit different micro-geographical layers as compared to the meso-geographical layers of the district. The interlaced liminal spaces created by the acquisition of resources in a community has a direct effect on property taxes and thus a school district's tax base. Still, a higher tax rate for Katy, Spring, Cy-Fair, and Humble ISD has not translated into a consistent and equitable distribution of educational resources across schools within the same district (Binkovitz and Mihir 2015; HISD, n.d.a.; Mellon, 2007; Spring ISD, 2007). This places low wealth and resource-scarce communities in these smaller districts squarely in the crosshairs of inequitable educational conditions and outcomes (Henig et al., 2001; Morrison et al., 2017). From a borderlands framework the conflict for resources often results in the politicization and commodification of education (Anzaldúa \& Keating, 2013). This situates education or schooling as a highly coveted yet restricted product rather than an open-ended opportunity for all students regardless of the community they live in. What is often overlooked are the families and communities that attempt to acquire resources but incur a penalty that places burdens on their cultural and racial sovereignty within the school district as the case with Spring ISD. As the case in Spring ISD, historically marginalized families are encouraged to belong but are reminded of that they are not a part of the community, which is an element of the borderland phenomenon (Anzaldúa \& Keating, 2013).

\section{Demographics}

The student enrollment data in each table affirm that for each of the urban emergent and characteristic districts, their racial, cultural, linguistic, and socioeconomic composition is becoming or is presently parallel to Houston ISD. This reality coincides with national data outlining how a racially, culturally, and linguistically monolithic teacher workforce is instructing classrooms filled with diverse learners (Hussar \& Bailey, 2013; U.S. Department of Education, 2016). Each district in its own right is diverse, which should prohibit the notion of diverse/diversity being strictly used as an overarching description of urban intensive school districts like HISD. When viewed through the borderlands theoretical framework, the problem with classifying urban school districts with terms such as "diverse", "minority", "students of color", "low-income", or "economically disadvantaged", is that those labels, without 
context, are coded portions of a lexicon/discourse immersed in racism and classism (Anzaldúa \& Keating, 2013). Rather than being open to interpretation through multiple contexts, these terms and phrases have come to imply that people of color are contaminates, while protecting the notion of a welcoming, White, middle-class ideology (Smith \& Stovall, 2008). The description of the urban intensive school districts, simply by race, disregards that race (and racism) are part of a web of realities (socioeconomics, language, nationality) in urban emergent and characteristic districts (Hochstenbach \& Musterd, 2018; Ladson-Billings \& Tate, 1995).

Diamond et al. (2020) argue that a deeper understanding is required from education scholarship concerning the complexities of suburban areas and growing rural areas. They reveal an unfortunate theme in urban education; the failure to deconstruct the predominantly White suburban phenomenon, and recognize the historical and contemporary fight that minoritized communities experience, across geographies, to avoid being erased from those landscapes (Diamond et al., 2020). Such historical struggle is often ignored in public discourse about urban, suburban, and rural schools and districts. Acknowledging such precedent, by teachers, researchers and policymakers is necessary to grasp the rich interdisciplinary and intergenerational narratives surrounding schools and their communities (Du Bois, 1899; Soja, 2005; Tate, 2008). The racial animus resulting from these struggles remain ever-present in the narratives of each independent school district. These tensions were brought forth by a multitude of conditions and elements such as school zone annexations or successions, rezoning of school attendance boundaries, the construction of transportation structures, geopolitical interests, gentrification, access to advanced placement courses, high-stakes testing performance, teacher quality, and teacher shortages in critical content areas (i.e., bilingualism, STEM); to which all are directly or tangentially tethered to race/ethnicity and thus language, culture, and nationality. This resistance/struggle for equity and equality, particularly in regard to securing equitable learning opportunities is a signature element of borderlands and each of the ISDs (Anzaldúa \& Keating, 2013; Buendia, 2011). To eliminate these elements (resistance and struggle for historically minoritized communities) a crosslayered (micro, meso, and macro), social justice focused, interdisciplinary collaboration amongst stakeholders (i.e., education practitioners, researchers, policymakers, corporations, and communities) is warranted (Anzaldúa, 1987; Buras, 2011; Soja, 2010).

\section{Conclusion}

The case of Harris County, Texas is not unique, but is common in other larger regions as well (i.e., New York City, Charlotte-Mecklenburg, North Carolina, Orange County, Florida). Yet, this case returns us back to Milner's (2012) salient inquiry and typology, "But what is urban education?". In light of multiple transnational issues that schools are faced with (i.e., transnationalism, immigration, migration, housing costs, labor changes, COVID-19), the response should be met with a resounding acknowledgement that "we all are" to some degree. From the 
data that was presented, the attempt to address inequities pertaining to education by each school district is mired in boundaries that shape who can escape these inequities. Simply splicing school districts based on race ignores the structural boundaries (transportation, city borders, etc.), and simply adhering to improving conditions based on location ignores the persistence of poverty driven to differential housing and job markets. Inequality and lack of access to high quality education that transcends race and class, and are driven by common structural boundaries and aliments within and across school districts. Often solutions for conditions plaguing urban learning environments gloss over the nuanced approach that is required to address inequalities, all while excluding populations and school districts that do not fit neatly within the critical conversations concerning urban education. We extended this typology to infer that usage of urban education as term or classification requires more than a meso-layered examination or cursory declaration of what makes a school district urban intensive, emergent, or characteristic; rather, to appropriately invoke these classifications necessitates stakeholders to analyze the historical, racial, cultural, temporal, and spatial conditions that constrict and/or expand individual schools '- - and thus students' — access to high quality educational opportunities and outcomes regardless of the zip code they live.

\section{Declarations}

Conflict of interest We declare that there are no conflict of interests, financial or otherwise, in the creation of this manuscript.

\section{References}

American Community Survey. (2018). 5-year estimate data profiles. U.S. Census Bureau. Retrieved August 21, 2020, from https://www.census.gov/acs/www/data/data-tables-and-tools/data-profiles/ $2018 /$.

Amrein-Beardsley, A., \& Geiger, T. (2017). All sizzle and no steak: Value-added model doesn't add value in Houston. Phi Delta Kappan, 99(2), 53-59.

Anderson, L. M., \& Stillman, J. A. (2013). Student teaching's contribution to preservice teacher development: A review of research focused on the preparation of teachers for urban and high-needs contexts. Review of Educational Research, 83(1), 3-69. https://doi.org/10.3102/0034654312468619

Anzaldúa, G. (1987). Borderlands/La Frontera: The new mestiza. Aunt Lute Books.

Anzaldúa, G., \& Keating, A. (Eds.). (2013). This bridge we call home: Radical visions for transformation. Routledge.

Bee, A. (2012). Household income inequality within US counties: 2006-2010. U.S. Department of Commerce, Economics and Statistics Administration, U.S. Census Bureau. Retrieved December 31, 2020, from https://www2.census.gov/library/publications/2012/acs/acsbr10-18.pdf.

Bell, D. A. (1995). Who's afraid of critical race theory. University of Illinois Law Review, 4, 893-910.

Benson, J. (2020). 'We don't care who you are': Race, space, and dispossession in New York's charter school co-location reform. Policy Futures in Education, 18(5), 662-680. https://doi.org/10.1177/ 1478210319875385

Binkovitz, L, \& Mihir, Z (2015, March 15). School districts seeing rise in poor students. Houston Chronicle. Retrieved December 31, 2020, from https://www.houstonchronicle.com/news/education/artic le/School-districts-seeing-rise-in-poor-students-6136011.php. 
Buendía, E. (2011). Reconsidering the urban in urban education: Interdisciplinary conversations. The Urban Review, 43(1), 1-21. https://doi.org/10.1007/s11256-010-0152-z

Bullard, R. D. (1983). Solid waste sites and the Black Houston community. Sociological Inquiry, 53(23), 273-288. https://doi.org/10.1111/j.1475-682x.1983.tb00037.x

Buras, K. (2011). Race, charter schools, and conscious capitalism: On the spatial politics of whiteness as property (and the unconscionable assault on black New Orleans). Harvard Educational Review, 81(2), 296-331. https://doi.org/10.17763/haer.81.2.6142343qqw360j03

Chakraborty, J. (2020). Unequal proximity to environmental pollution: An intersectional analysis of people with disabilities in Harris County, Texas. The Professional Geographer, 72(4), 521-534. https://doi.org/10.1080/00330124.2020.1787181

Children at Risk. (2017). The state of public education in Texas: 2017 school rankings analysis. http:// childrenatrisk.org/wp-content/uploads/2017/06/The-state-of-public-education-in-Texas-schoolrankings-analysis.pdf

Chukhray, I., \& Salazar, E. S. (2019). Harris County's College Advising Needs. (Research Report for the Houston Independent School District 7, Issue 2). Houston Education Research Consortium. Retrieved December 31, 2020, from https://files.eric.ed.gov/fulltext/ED598202.pdf.

Clettenberg, S., Gentry, J., Held, M., \& Mock, L. A. (2011). Traumatic loss and natural disaster: A case study of a school-based response to Hurricanes Katrina and Rita. School Psychology International, 32(5), 553-566. https://doi.org/10.1177/0143034311402928

Cypress Fairbanks Independent School District. (2013). An overview of Cypress-Fairbanks Independent School District. Retrieved December 31, 2020, from http://www.cfisd.net/aboutour.

Cypress Fairbanks Independent School District. (n.d.). History of CFISD. Retrieved December 31, 2020, from https://www.cfisd.net/en/about/know-your-district/history.

DeCuir, J. T., \& Dixson, A. D. (2004). "So when it comes out, they aren't that surprised that it is there": Using critical race theory as a tool of analysis of race and racism in education. Educational Researcher, 33(5), 26-31. https://doi.org/10.3102/0013189x033005026

Delgado-Bernal, D. (1998). Using a chicana feminist epistemology. Harvard Educational Review, 68(4), 555-82. https://doi.org/10.17763/haer.68.4.5wv1034973g22q48

Delgado-Bernal, D. (2002). Critical race theory, Latino critical theory, and critical raced-gendered epistemologies: Recognizing students of color as holders and creators of knowledge. Qualitative Inquiry, 8(1), 105-126. https://doi.org/10.1177/107780040200800107

Diamond, J. B., Posey-Maddox, L., \& Velázquez, M. D. (2020). Reframing suburbs: Race, place, and opportunity in suburban educational spaces. Educational Researcher. Advance online publication. Retrieved December 31, 2020, from https://doig.org/0013189X20972676.

Dixson, A. D., Ladson-Billings, G., Suarez, C. E., Trent, W. T., \& Anderson, J. D. (2020). Condition or process? Researching race in education. American Education Research Association.

Du Bois, W. E. B. (1899). The Philadelphia negro: A social study. University of Philadelphia.

Du Bois, W. E. B. (1903). The souls of black folk. Oxford University Press.

Elenes, A. C. (1997). Reclaiming the borderlands: Chicana/o identity, difference, and critical pedagogy. Educational Theory, 47(3), 359-376. https://doi.org/10.1111/j.1741-5446.1997.00359.x

Elenes, C. A., \& Bernal, D. D. (2010). Latina/o education and the reciprocal relationship between theory and practice: Four theories informed by the experiential knowledge of marginalized communities. In Handbook of Latinos and education (pp. 89-115). Routledge.

Farmer, S., Poulos, C. D., \& Baber, A. (2020). Challenging the market logic of school choice: A spatial analysis of charter school expansion in Chicago. Journal of Urban Affairs, 42(4), 511-533. https:// doi.org/10.1080/07352166.2018.1555437

Gabe, T., Falk, E. H., Mason, V. W., \& McCarty, M. (2005, November). Hurricane Katrina: Socialdemographic characteristics of impacted areas. Congressional Research Service, Library of Congress. Retrieved December 31, 2020, from https://www.hsdl.org/?view\&did=457694.

Galaskiewicz, J., Anderson, K. F., \& Thompson-Dyck, K. (2019). Minority-White income inequality across metropolitan areas: The role of racial/ethnic residential segregation and transportation networks. Journal of Urban Affairs. https://doi.org/10.1080/07352166.2019.1660581

Graif, C. (2016). (Un) natural disaster: Vulnerability, long-distance displacement, and the extended geography of neighborhood distress and attainment after Katrina. Population and Environment, 37(3), 288-318. https://doi.org/10.1007/s11111-015-0243-6

Grineski, S., Collins, T. W., Chakraborty, J., \& Montgomery, M. (2015). Hazardous air pollutants and flooding: A comparative interurban study of environmental injustice. GeoJournal, 80(1), 145-158. https://doi.org/10.1007/s10708-014-9542-1 
Harris, C. I. (1993). Whiteness as property. Harvard Law Review, 106(8), 1707-1791. https://doi.org/10. 2307/1341787

Henig, J. R., Hula, R. C., Orr, M., \& Pedescleaux, D. S. (2001). The color of school reform: Race, politics, and the challenge of urban education. Princeton University Press.

Herrera, S. (2017a, March 25). In Houston's Katy suburb, a Venezuelan population thrives. Houston Chronicle. Retrieved December 31, 2020, from https://www.houstonchronicle.com/news/houstontexas/houston/article/In-Houston-s-Katy-suburb-a-Venezuelan-population-11028051.php.

Herrera, S. (2017b, May 30). In Katy school district, highway divides academic performance results. Houston Chronicle. Retrieved December 31, 2020, from https:/www.houstonchronicle.com/news/ houston-texas/education/article/In-Katy-school-district-highway-divides-academic-11183576.php.

Hochstenbach, C., \& Musterd, S. (2018). Gentrification and the suburbanization of poverty: Changing urban geographies through boom and bust periods. Urban Geography, 39(1), 26-53. https://doi. org/10.1080/02723638.2016.1276718

Houston Independent School District. (n.d.a). Adopted district budget 2016-2017. Houston Independent School District, Office of Budgeting and Financial Planning. Retrieved December 31, 2020, from https://www.houstonisd.org/site/handlers/filedownload.ashx ? moduleinstanceid=213604\&dataid= 189613\&FileName=Adopted\%20Budget\%20Book\%20with\%20Bookmarks2016-17.pdf.

Houston Independent School District. (n.d.b). Resource allocation handbook 2016-2017. Houston, TX: Houston Independent School District, Department of Research and Accountability. Retrieved December 31, 2020, from https://www.houstonisd.org/site/handlers/filedownload.ashx?modul einstanceid=81052\&dataid=172632\&FileName=2016-2017\%20RAS\%20--Updated\%2009-07-16. pdf.@@@

Humble Independent School District. (2016). Advance academics 2016-2019 department lan. https:// www.humbleisd.net/cms/lib/TX01001414/Centricity/Domain/5643/Advanced\%20Academics\% 20Improvement\%20Plan.pdf.

Hussar, W. J., \& Bailey, T. M. (2013). Projections of Education Statistics to 2022 (NCES 2014-051). U.S. Department of Education, National Center for Education Statistics. U.S. Government Printing Office. Retrieved December 31, 2020, from https://files.eric.ed.gov/fulltext/ED544761.pdf.

Irby, D. J. (2015). Urban is floating face down in the mainstream: Using hip-hop-based education research to resurrect "the urban" in urban education. Urban Education, 50(1), 7-30. https://doi.org/10.1177/ 0042085914563183

Jackson, A. M., \& Ahmed, F. (2020). Assessing characteristics of unplanned school closures that occurred in the United States in response to Hurricane Harvey in 2017. Disaster Medicine and Public Health Preparedness, 14(1), 125-129. https://doi.org/10.1017/dmp.2019.159

Katy Independent School District. (n.d.) Katy ISD. Retrieved December 31, 2020, from http://www.katyi sd.org/Pages/default.aspx.

Kinder Institute for Human Research. (2019). Neighborhood gentrification across Harris County: 19902016. Retrieved December 31, 2020, from https://kinder.rice.edu/research/neighborhood-gentrifica tion-acrossharris-county-1990-2016.532.

King, L. O., \& Lowe, J. S. (2018). "We want to do it differently": Resisting gentrification in Houston's Northern Third Ward. Journal of Urban Affairs, 40(8), 1161-1176. https://doi.org/10.1080/07352 166.2018.1495039

Klineberg, S. L. (2018). The 2018 Kinder Houston area survey: Tracking responses to income inequalities, demographic transformations, and threatening storms. Kinder Institute for Urban Research.

Klineberg, S. L., \& Wu, J. (2013). Houston Area Asian survey: Diversity and transformation among Asians in Houston Findings from the Kinder Institute's Houston area Asian survey (1995, 2002, 2011). Kinder Institute for Urban Research.

Klineberg, S. L., Wu, J., \& Douds, K. (2013). The 2012 Houston education survey: Public perceptions in a critical time. Kinder Institute for Urban Research.

Ladson-Billings, G. (1998). Just what is critical race theory and what's it doing in a nice field like education? International Journal of Qualitative Studies in Education, 11(1), 7-24.

Ladson-Billings, G., \& Tate, W. F. (1995). Toward a critical race theory of education. Teachers College Record, 97(1), 47-68. https://doi.org/10.4324/9781003005995-2

Linder, S. H., Marko, D., \& Sexton, K. (2008). Cumulative cancer risk from air pollution in Houston: Disparities in risk burden and social disadvantage. Environmental Science \& Technology, 42(12), 4312-4322. https://doi.org/10.1021/es072042u

Iossifova, D. (2013). Searching for common ground: Urban borderlands in a world of borders and boundaries. Cities, 34, 1-5. 
Lugones, M. (1990). Hispaneando y lesbiando: On Sarah Hoagland's lesbian ethics. Hypatia, 5(3), 138-146.

Lupkowski, A. E. (1984). Gifted students in small rural schools do not have to move to the city. Roeper Review, 7(1), 13-16. https://doi.org/10.1080/02783198409552834

Matsuda, M. J. (1991). Voices of America: Accent, antidiscrimination law, and a jurisprudence for the last reconstruction. Yale Law Journal, 1329-1407.

McIntosh, M. F. (2008). Measuring the labor market impacts of Hurricane Katrina migration: Evidence from Houston, Texas. American Economic Review, 98(2), 54-57. https://doi.org/10.1257/aer.98.2. 54

Mellon, E. (2007, April 5). Suburban succession/Neighbors petition to join Klein/Northgate Forest residents complain of lower property values and performance with Spring. Houston Chronicle. Retrieved December 31, 2020, from https://web.archive.org/web/20080317135628/http://www. chron.com/CDA/archives/archive.mpl?id=2007_4319053.

Milner, H. R., IV. (2008). Disrupting deficit notions of difference: Counter-narratives of teachers and community in urban education. Teaching and Teacher Education, 24(6), 1573-1598. https://doi. org/10.1016/j.tate.2008.02.011

Milner, H. R., IV. (2012). But what is urban education? Urban Education, 47(3), 556-561.

Milner, H. R., IV., \& Lomotey, K. (Eds.). (2013). Handbook of urban education. Routledge.

Milner, H. R., IV., Murray, I. E., Farinde, A. A., \& Delale-O'Connor, L. (2015). Outside of school matters: What we need to know in urban environments. Equity \& Excellence in Education, 48(4), 529548. https://doi.org/10.1080/10665684.2015.1085798

Mirel, J. (1993). School reform, Chicago style: Educational innovation in a changing urban context, 1976-1991. Urban Education, 28(2), 116-149. https://doi.org/10.1177/0042085993028002002

Moon, J. (2018). HISD's decentralization reform (Part II: Principal survey). (Research Brief for the Houston Independent School District 6, Issue 3). Houston Education Research Consortium. Retrieved December 31, 2020, from https://files.eric.ed.gov/fulltext/ED598240.pdf.

Moreno, J. (2004, August 15). Houston is home to many workers leaving Venezuela. Houston Chronicle. Retrieved December 31, 2020, from https:/www.chron.com/news/houston-texas/article/Houstonis-home-to-many-workers-leaving-Venezuela-1642632.php.

Morrison, D., Annamma, S. A., \& Jackson, D. D. (Eds.). (2017). Critical race spatial analysis: Mapping to understand and address educational inequity. Stylus Publishing, LLC.

Mortensen, K., Wilson, R., \& Ho, V. (2009). Physical and mental health status of Hurricane Katrina evacuees in Houston in 2005 and 2006. Journal of Health Care for the Poor and Underserved, 20(2), 524-538. https://doi.org/10.1353/hpu.0.0130

National Center for Education Statistics. (2018). Enrollment, poverty, and federal funds for the 120 largest school districts, by enrollment size in 2015, 2014-2015 through 2017. Retrieved 2018, from https://nces.ed.gov/programs/digest/d17/tables/dt17_215.30.asp.

Newman, D. (2003). On borders and power: A theoretical framework. Journal of Borderlands Studies, 18(1), 13-25. https://doi.org/10.1080/08865655.2003.9695598

Noguera, P. (1996). Confronting the urban in urban school reform. The Urban Review, 28(1), 1-19. https://doi.org/10.1007/bf02354375

Podagrosi, A., Vojnovic, I., \& Pigozzi, B. (2011). The diversity of gentrification in Houston's urban renaissance: From cleansing the urban poor to supergentrification. Environment and Planning A, 43(8), 1910-1929. https://doi.org/10.1068/a43526

Population and Survey Analysts. (2018). Katy demographic update fall 2018. Retrieved December 31, 2020, from https://www.katyisd.org/abm/Documents/KatyISD_Demographic_Report_2018.pdf.

Price, L. E., Cramer, E., Milanowski, A., Mader, J., Robertson, D., \& Stevens, C. J. (2019). Teacher incentive fund STEM grant in Houston ISD: A human capital approach to improving STEM education. Research Educational Program Report. Houston Independent School District.

Roza, M., \& Warco, A. (2015). Paying the best teachers more to teach more students. Edunomics Lab at Georgetown University.

Ruiz de Castilla, V. (2018). Teacher certification and academic growth among English learner students in the Houston Independent School District. [Policy brief]. Regional Educational Laboratory Southwest. https://texaserc.utexas.edu/wp-content/uploads/2017/12/47-Brief-REL-SW-12.19.17.pdf.

Sarnoff, N. (2000, April, 21) Builder bucks odds with new homes in old areas. Houston Business Journal. Retrieved December 31, 2020, from http://houston.bizjournals.com/houston/stories/2000/04/ 24/story3.html. 
Schaffer, C. L., White, M., \& Brown, C. M. (2018). A tale of three cities: Defining urban schools within the context of varied geographic areas. Education and Urban Society, 50(6), 507-523. https://doi. org/10.1177/0013124517713605

Shaw, M. (2017). Creating the urban educational desert through school closures and dignity taking. Chicago-Kent Law Review, 92(3), 1087-1114.

Solórzano, D. G., \& Yosso, T. J. (2002). Critical race methodology: Counterstorytelling as an analytical framework for education research. Qualitative Inquiry, 8(1), 23-44. https://doi.org/10.1177/10778 00402008001003

Soja, E. W. (2005). Borders unbound. Globalization, regionalism, and the postmetropolitan transition. B/ ordering Space, 33-46.

Soja, E. (2010). Spatializing the urban, Part I. City, 14(6), 629-635.

Smith, J. J., \& Stovall, D. (2008). 'Coming home'to new homes and new schools: critical race theory and the new politics of containment. Journal of Education Policy, 23(2), 135-152.

Spencer, J. (2007, March 12). A new kind of white flight? Houston Chronicle. Retrieved December 31, 2020, from https://blog.chron.com/k12zone/2007/03/a-new-kind-of-white-flight/.

Spring Independent School District. (2007, April, 2). Spring ISD Board Rejects Northgate Petition. Spring Independent School District. Retrieved December 31, 2020, from https://web.archive.org/ web/20150924105034/http:/www.springisd.org/default.aspx?name=apr07petition.

Spring Independent School District. (n.d.). Spring ISD then and now. Retrieved December 31, 2020, from https://www.springisd.org/Page/897.

Stroub, K. J., \& Richards, M. P. (2016). Evaluating the impact of school closures in Houston ISD Part I: The effect of school closures on patterns of student attendance and achievement. Education Research Center, The University of Texas at Austin. https://texaserc.utexas.edu/wp-content/uploa ds/2017/12/27-Brief-School-Closure.pdf.

Tate, W. F., IV. (2008). "Geography of opportunity": Poverty, place, and educational outcomes. Educational Researcher, 37(7), 397-411. https://doi.org/10.3102/0013189x08326409

Texas Education Agency (TEA) (2004). Academic excellence indicator system. Retrieved December 31, 2020, from http:www.tea.state.tx.us/perfreport/aeis/2004.

Texas Education Agency (TEA). (2005). Academic excellence indicator system. Retrieved December 31, 2020, from http://www.tea.state.tx.us/perfreport/aeis/2005

Texas Education Agency (TEA). (2006). Academic excellence indicator system. Retrieved December 31, 2020, from http://www.tea.state.tx.us/perfreport/aeis/2006.

Texas Education Agency (TEA). (2014). 2014 Accountability manual for Texas public school districts and campuses. Retrieved December 31, 2020, from http://ritter.tea.state.tx.us/perfreport/account/ 2014/manual/index.html.

Texas Education Agency (TEA). (2018a). Cypress-Fairbanks Independent School District, Texas academic performance report 2016-2017. Retrieved December 31, 2020, from https://rptsvr1.tea. texas.gov/perfreport/tapr/2017/srch.html?srch=D.

Texas Education Agency (TEA). (2018b). Humble Independent School District, Texas academic performance report 2016-2017. Retrieved December 31, 2020, from https://rptsvr1.tea.texas.gov/perfr eport/tapr/2017/srch.html?srch=D.

Tobin, K. J. (2016). Homeless students and academic achievement: Evidence from a large urban area. Urban Education, 51(2), 197-220. https://doi.org/10.1177/0042085914543116

Turner, E. O., \& Spain, A. K. (2020). The multiple meanings of (in) equity: Remaking school district tracking policy in an era of budget cuts and accountability. Urban Education, 55(5), 783-812. https://doi.org/10.1177/0042085916674060

Tyack, D. B. (1974). The one best system: A history of American urban education. Harvard University Press.

U.S. Department of Education. (2015). National Assessment of Educational Progress (NAEP) 2009, 2011, 2013 and 2015 mathematics and reading Assessments. Institute of Education Sciences, National Center for Education Statistics. Retrieved December 31, 2020, from http://www.natio nsreportcard.gov.

U.S. Department of Education. (2016). The state of racial diversity in the educator workforce. Retrieved December 31, 2020, from http://www2.ed.gov/rschstat/eval/highered/racial-diversity/state-racialdiversityworkforce.pdf.

U.S. Census Bureau. (2019). Quickfacts: 2018 population estimates of Harris County, Texas. Retrieved December 31, 2020, from https://www.census.gov/quickfacts/harriscountytexas. 
U.S. Census Bureau. (2020). U.S. Census Bureau 2010-2020 Census redistricting data (Public Law 94-171).

U.S. Census Bureau. (n.d.a). Quickfacts: Katy, Texas population estimates 2010. Retrieved December 31, 2020, from https://www.census.gov/quickfacts/fact/table/katycitytexas/PST040219.

U.S. Census Bureau. (n.d.b.). Katy, Texas general demographic profile for the year 2000. https://data. census.gov/cedsci/table?q=Katy\%20Texas\%202000\&tid=DECENNIALSF12000.H008\&hideP review $=$ false.

Vélez, V. N., \& Solórzano, D. G. (2017). Conceptualizing GIS as a tool for critical race research in education. In D. Morrison, S. A. Annamma, \& D. D. Jackson (Eds.), Critical race spatial analysis: Mapping to understand and address educational inequity (pp. 126-146). Stylus, LLC.

Wallace, T. L., \& Chhuon, V. (2014). Proximal processes in urban classrooms: Engagement and disaffection in urban youth of color. American Educational Research Journal, 51(5), 937-973.

Watson, D. (2011). What do you mean when you say "urban"? Speaking honestly about race and students. Rethinking Schools, 26(1), 48-50.

Welsh, R. O., \& Swain, W. A. (2020). (Re) defining urban education: A conceptual review and empirical exploration of the definition of urban education. Educational Researcher, 49(2), 90-100. https:// doi.org/10.3102/0013189x20902822

Williams III, J., Bryant, A. C. \& Lewis, C. (2018). Education, economics, \& segregation in Baton Rouge. In K. J. Fasching-Varner, K. J. Tobin, \& S. M. Lentz, (Eds.), Black deaths, \& blue ribbons (pp. 111-116). Brill Sense.

Publisher's Note Springer Nature remains neutral with regard to jurisdictional claims in published maps and institutional affiliations. 